\title{
GLOBALIZATION AND RELIGIOUS IDENTITY
}

\author{
John Campbell-Nelson \\ Lecturer of Practical Theology at the Theological Faculty of \\ Artha Wacana Christian University (UKAW) Kupang
}

\begin{abstract}
ABSTRAK
Materialisme, konsumerisme, dan individualisme dikampanyekan berasal dari Barat dan mengancam karakter moral masyarakat beragama, terutama kaum muda dari berbagai penganut agama. Benarkah demikian? Perlu dicatat bahwa globalisasi berdampak luas pada identitas budaya dan agama, namun tidak berarti selalu bermakna dampak negatif dan disintegrasi. Globalisasi dapat juga memiliki efek memperkaya, memperkuat dan membuat budaya lokal lebih fleksibel. Untuk itu perlu dicarikan metode dan mekanisme yang menjadikan globalisasi berdampak positif terhadap identitas suatu agama, terlebih lagi, memang beberapa agama berasal dari sumber yang sama, yakni agama yang dikenal dengan abrahamic religion (Islam, Nasroni, dan Yahudi).
\end{abstract}

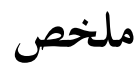

المادية والنزعة الاستهاكية والفردية حملت من الغرب وهلدت الطابع الأخلاقي للمجتمعات الدينية، وخاصة الشباب من مختلف الأديان. فهل هذا صحيح؟ وبحدر الإشارة إلى أن تأثير العولمة واسع على الهوية الثقافية والدين ولكن ليس بمعنى آثار سلبية والتفكك. قد تكون العولمة أيضا لها تأثير ضمان، وتعزيز وجعل الثقافة المحلية أكثر مرونة. لذلك بحاجة إلى البحث عن وسائل وآليات بتحل العولمة لها تأثير إيجابي على هوية الدين. وعلاوة على ذلك، فإن بعض الأديان تأتي من نفس المصدر، وهو الدين المعروف باسم الأديان الإبراهيمية (الإسلام والمسيحية واليهودية).

Key words: Globalization, Religious Identity, and individuation 


\section{A. Introduction}

When I first arrived in Timor in 1983, I quickly learned that Indonesian national culture presented many opportunities to listen to speeches. One of the themes current at the time was the danger of "materialism, consumerism, and individualism." Governors, regents, village heads, and church officials routinely warned that this trio of demons was threatening the moral character of the people, especially the young. These bad influences came from "the West," and if we weren't careful our churches would soon be empty just like those in Europe. As I sat in the audience listening to these dire warnings, no one seemed to notice the irony that I, a Westerner, had been invited to teach in a protestant seminary in Timor - where I would presumably have some influence on the moral character of the young.

In time, the evil trio gained a collective name - globalization - but the trope in public discourse remained much the same: an innocent, pristine indigenous community was under threat from a foreign cultural invader, and it was the responsibility of political and religious leaders to warn and defend the people. Indeed, the defense of local identity became a powerful tool for legitimizing the leadership of those making the speeches. Perhaps in a subliminal way it was as if they were positioning themselves as heirs of the Revolution, casting out the colonizers once again.

The rhetoric has since cooled considerably as globalization has become a fact of everyday life. But the positioning of public leaders as defenders of local identity has scarcely diminished. Nor can it be denied that globalization has had a profound effect on cultural and religious identity, although it is by no means certain that the effect has been entirely negative and disintegrative. It is equally possible that globalization has had an enriching effect, and rather than destroying local identity has strengthened it and made it more flexible. Perhaps it is time for a more nuanced discussion of the effects of globalization. That is what I want to attempt in this paper, with special attention to religious identity, at least as I see it from my vantage point in a majority Christian area of Eastern Indonesia.

Since we are to speak of identity, allow me to begin with a few words about where I come from. 


\section{B. Before Globalization}

In the small town in the Midwestern US state of Iowa where I was born everyone was white. Most of us were of either Anglo Saxon or German descent. There were no Asians, no Latin Americans, not even any Native Americans or African Americans. There was a small clan of Gypsies who came in the summers to work in the carnival, but they kept to themselves. The only minority group that we actually identified as such and encountered on a daily basis was Catholics. We Protestants called them "mackerel snappers" because they ate fish on Fridays.

The boys played Cowboys and Indians, and whoever had the role of Indian had to be ready to fall down a lot because he was sure to be shot, just like in the movies. For variety, we occasionally shifted to World War II and shot Krauts (Germans) and Japs. Sometimes I asked to borrow the German helmet my father had brought home as a souvenir of the war.

We told Polish jokes, in which the Polish were always portrayed as stupid, even though we didn't actually know any Polish people-or maybe precisely because we didn't know any Polish people; that way no one would be offended. My father's generation also told Nigger jokes, but we had heard the speeches of Martin Luther King on television and were taught in school to respect Abraham Lincoln because he had freed the slaves and saved the Union. Besides, the Civil Rights Movement was just getting under way, and our pastor went to the South to join in the marches. So we felt a little squeamish laughing at Nigger jokes.

As for Muslims, they were a distant mystery. There was not a single mosque in Iowa at that time, and no one I knew had ever met a Muslim. We confused Muslims with Arabs, and all I knew about Arabs I learned from the popular song, "Ahab the Arab". The lyrics are too awful for me to repeat here, but in sum they present a racial and ethnic stereotype of the Arab male riding through the desert on his camel, and end with him sneaking into the Sultan's harem for a tryst with his girl friend Fatima (who is dressed as a belly dancer, of course). He finds her drinking Coca Cola, listening to American music, and reading Mad magazine. Beneath the exoticism she was just another American wannabe.

Being boys, we were interested in naked women. In the days before Playboy magazine, the best we could manage was an occasional peek at a bare-breasted 
tribal woman in National Geographic. In fact, most of my images of the world beyond the United States, I gained from the pages of that venerable magazine.

I met my first African American at church camp, and my first Indonesian as well. The first Chinese woman I ever met was the wife of a Methodist pastor who had married her when he was a missionary there. My first non-American friends were fellow students at the small church-related college I attendedthey were studying in the U.S. on scholarships from the Methodist Church.

My seminary studies introduced me to Latin American liberation theology, with its critique of the ideological bondage of North American Christianity to the interests of global capitalism. My work on Kierkegaard for my dissertation made me painfully aware of the difference between being a Christian and merely being born in a Christian-dominated society. I began to wonder what it would be like to be a Christian in a radically different culture. When the mission board of our church offered the opportunity to teach theology at a seminary in Timor, my wife and I got out the map and finally located Timor out on the edge of Indonesia, just north of Darwin, Australia. That seemed like it would be different enough.

Thirty years later, we are still there. As I look back on it, long before the word "globalization" was coined, the church was the principle agent of introducing me to a larger world and the variety of human beings who inhabit it. I don't propose either an apology or a critique of the missionary enterprise here. What I have to say for the most part applies to Islam as well as to Christianity. Of the global religions, these two have historically the strongest call to mission within their respective belief systems, and as such they have for centuries been agents of globalization, as they continue to be in the present.

Often the discourse on globalization within religious communities is reactive. We bemoan our loss of hegemony, fret over the inroads made by competing religious groups, grieve over the economic and ecological disasters that fill our newspapers and television screens, and generally struggle with issues we had never thought about until they arrived on our doorstep. But we are also active, not only as consumers but as agents of globalization. We read, we engage in dialogue, we hold conferences, we travel if we can afford it, or we provide hospitality for those who come to us. We support institutions that represent us on the global stage, and we engage in acts of solidarity with people far away 
whom we will likely never meet. Globalization is not merely a sort of virus that infects our religious identity; we are actively re-forming our religious identity in the face of globalization by our actions and the choices we make. Moreover, for monotheistic religions, globalization is in some sense an article of faith, a matter I will take up again at the end of this paper.

In the comments that follow, I will assume that by now we have in mind a framework for thinking about globalization. For the record, I am content to use the well-known definitions offered by Roland Robertson and Anthony Giddens:

Globalization is "the compression of the world and the intensification of the consciousness of the world as a whole." ${ }^{1}$

Globalization can thus be defined as the intensification of worldwide social relations which link distant localities in such a way that local happenings are shaped by events occurring many miles away and vice versa. $^{2}$

With these definitions in mind, I want to look at religious identity in the context of globalization. I have no hope of adequately describing so vast a topic as the impact of globalization on religious identity. I'll be content to look for a path, to make suggestions about how we might think and talk about religious identity in the "global village" - or global marketplace, in which we find ourselves. In postmodern-speak, we will need to problematize religious identity.

\section{The Identity of Identity}

Identity in most cases is not consciously chosen or even noticed until it becomes a problem. People absorb their sense of self and their sense of belonging from their life histories long before they ever ask themselves the question, "Who am I?" That typically adolescent questions answered in many cultures by stimulating a choice of identity through various rites of passage (which often simulate a crisis or conflict, the resolution to which is the culturally accepted "answer" it is hoped will be elicited from the young people).

1 Roland Robertson, Globalization: Social Theory and Global Culture, (London: Sage, 1992), p. 8 .

Anthony Giddens. The Consequences of Modernity, (Stanford: Stanford University Press, 1990), p. 4. 
At middle age people may also have a "mid-life crisis" which is again about identity-coming to terms with the person one has become, marshalling our flagging resources in hopes of recovering some of the lost dreams of our youth. Whatever form it takes, such a period of identity review is given cultural sanction within reasonable limits.

Disasters such as floods and earthquakes or wars, as well as personal disasters such as the loss of a spouse, parent, child, or job, may also precipitate crises of identity. But outside of these periods of disturbance, identity is expected to be stable.

The English word "identity" only came into use in the late $16^{\text {th }}$ Century in its modern sense of referring to what is unique or distinctive about an individual's character or personality, and by extension to the distinguishing characteristics of a social group. It comes from the Latin idem, meaning "same." So identity refers at the outset to what remains the same even when other things change.

Here lies the first problem. What if it is in our nature to change? What happens to identity then, if identity means staying the same? Biologically we age, psychologically we mature, socially we interact with others and are affected by them. To refuse to change would be a denial of our identity as persons.

Oscar Wilde wrote a wonderful parable of identity and change in his short novel, "The Picture of Dorian Gray." Dorian was a vain young man who found the secret of eternal youth in a magical portrait of himself. The portrait would grow old, but he would remain youthful. He covered up the picture and stored it away, and went on with his carefree youth while others aged around him. But curiosity about what he really looked like began to consume him. Finally, he uncovered the portrait and was so appalled at what a hideous wretch he had become that he went mad and died. At least that's how I remember it. Wilde suggests that not to change is a kind of madness or corruption, because it is in our nature to change.

Some religious communities seem to use their teachings, their rituals, and their organizational structures as a magical portrait. They store them away and don't allow them to be examined, and go on living as if nothing could touch them. Then one day when the portrait is unveiled, they are shocked to find that they are near their deathbed.

Change, then, has to be seen as a part of any adequate concept of identity, at least where human beings are concerned. It cannot mean to remain the same, 
but rather to maintain some kind of continuity in the midst of change. I can think of two concepts that seem helpful here, and they apply both to individuals and to groups: growth and responsibility. Growth (in the sense of maturation) implies that what was present in potentia in the child is progressively realized in the qualities of the adult. For a religious community, growth may mean that aspects of their faith that were formerly merely preached and confessed become active in the life of the community and its service to others. Or it may mean that aspects of scripture or doctrine that were once only vaguely understood become articulated and clarified in the common understanding of the community. Numerical growth is meaningless without these more fundamental qualities. To the degree that globalization awakens dormant aspects of our religious traditions and draws us to clarify and implement them, we can say that globalization is an opportunity for growth - and to that degree an aid rather than a threat to religious identity.

Responsibility means literally the ability to respond, and response is a kind of change brought forth by the other to whom we respond. Anyone who has known the changes brought forth in us when we first become parents will understand this. People and groups are called "responsible" if they respond to others in a way that is trustworthy. In terms of our religious identity, the basis of this trustworthiness is to respond to change in accordance with our loyalty to the basic values and principles of our faith, as best we understand them. In the process of action and response, we may come to a new understanding of our faith which in turn leads us to respond differently in the future. But at least it will be part of a history of responsibility that is intelligible, both to ourselves and to the other to whom we respond. For more on this, see H. Richard Niebuhr's classic The Responsible Self (1963), in which he articulates an ethic of responsibility that is remarkably well suited to dealing with the complexities of globalization.

Implicit in these two concepts, growth and responsibility, is another way of looking at identity: narrative. If you were asked to explain who you are, I suspect that you would not reply with a set of moral or religious principles that you hold in highest esteem. You would probably tell a story. It would include where you came from and what you have done and what happened to you and how you responded and how you came to be where you are now. 
There is no reason that we can't conceive of religious identity in the same way. When we tell stories, the problem of continuity in change is resolved by the narrative itself, by the history of action and response and subsequent growth. For a wonderful example of this, see the Acts of the Apostles, Ch. 10. Peter the observant Jew has a vision in which all kinds of non-kosher food are set before him, and a heavenly voice tells him to eat. He protests that this is against his religion. The voice answers, "What God has made clean, you must not call unclean." After the vision ends, he is called by a messenger to go to the house of Cornelius, a Roman centurion who wants to hear what Peter has to say about Jesus. As a good Jew, Peter should not even enter the house of an unclean "kafir" such as Cornelius. But he goes, and finds that Cornelius believes what he says and wants to join the community of faith. Up until then, the followers of Jesus had seen Christianity as a reform movement within the Jewish community. No gentiles (non-Jews) were accepted. Peter now understands the meaning of his dream (unacceptable foods = unacceptable people), and draws the radically new conclusion: "Now I see that God shows no partiality, but in every nation anyone who fears him and does what is right is acceptable to him."3

This is of course a key text for Christians about globalization. Note that the focus of the story is not on Cornelius' conversion to Christianity, but on Peter's conversion to acceptance of the other. It is a radical change of religious identity for Peter, and subsequently for the whole Christian movement. And it only makes sense when you know the story.

These are three themes that I can offer, then: growth, responsibility, and narrative (whether personal biography or common history) for how we can face the challenges of globalization to religious identity without losing our way in the forest.

Implicit in these three themes are the personal, the communal, and the ideational or theological aspects of religious identity. I now want to deal with each of them in a somewhat more focused way.

\section{Globalization and Individuation}

The various religions have their own ways of defining those aspects of identity that count, if not for salvation at least for a claim to membership. Islam has the

3 Acts $10.34-35$. 
Five Pillars, Buddhism the four noble truths and the eight-fold path. Martin Luther said, "All you need to know is that you are baptized" (the rest is a matter of learning to trust God). For indigenous religions, it is usually enough to be born into the tribe.

In a general sense, the identity questions that religion asks and answers are very simple: Who am I? Where did I come from and where do I belong? What am I here for? Of course nations, cultures, ideologies, and ethnic groups also offer their own answers to some of these questions. Much depends on whether we view them from the point of view of a religious community or from the perspective of the individual. In most of what I have to say below, I will have the religious community in mind, but first I want to make a few comments on the question of individual identity. Seen from the individual's perspective, these are existential questions (which admittedly some people take more seriously than others).In the end they are answered over the course of a lifetime in our own autobiographies.

Most communities observe some form of a rite of passage from child to adult, and religious communities are no different. Whether it is Christian Confirmation (or adult baptism), Bar Mitzvah, or circumcision, the individual stands up and makes a profession of faith (usually accompanied by rituals or symbols of transformation) that marks his or her transition from child to adult and the assumption of full rights and responsibilities as a member of the religious community. Various forms of religious education that prepare the child (usually an adolescent) for this transformation form the reproductive system of the religious community. As with reproduction in general, this process is carefully guarded to prevent "pollution" from outside influences.

Globalization makes such protection extremely difficult. It greatly expands the range of possibilities presented to young people, and at the same time intensifies the role of individual choice in negotiating these possibilities. We will analyze just how it does this in a moment, but first it may be helpful to look at the psychosocial dynamics that underlie this crucial period of identity formation.

The psychologist Erik Erikson ${ }^{4}$ developed a framework for understanding human psychosocial development by dividing it into eight stages, each with a

4 Erik Erikson, The Life Cycle Completed, (New York: Norton, 1985). 
corresponding "developmental crisis," the resolution of which moves us on to the following stage. A successful resolution to the crisis builds "ego strength" more or less what we would call "virtues" or "character" in ordinary language. Appropriate to our topic, Erikson sees the distinctive developmental crisis of adolescence as "Identity vs. Identity Confusion." As Erikson sees it, adolescents are typically engaged in gathering and evaluating the raw materials of what will become their personal identity as adults. They gather these raw materials not only from their religious communities, but also from school, social interactions (especially with peers), and in their interaction with their cultural environment. This is consistent with the general observation that teenagers are rapid adopters of whatever global "cargo" floats their way (often just as rapidly discarding it in favor of the next new thing). This is true not only with fashion, foods, music, TV and films, but also with ideas and values. All this "trying on", keeping and rejecting, builds in them by practice, as it were, a growing sense of the values and commitments that ground their choices. Awareness of this set of core commitments is the "ego strength" of the adolescent stage, which Erikson calls fidelity. To fail in this task of developing the moral core that holds our personality together is to fall into "identity confusion," a condition in which a person remains labile, easily drawn to new possibilities and just as easily abandoning them.

Globalization presents not only teenagers but everyone with a rapidly changing array of possibilities and choices that were not foreseen in our native cultural contexts or mentioned in our religious education, and which may have ambiguous implications for our existing value systems. In Erikson's scheme of psychosocial development, issues not adequately dealt with at a prior stage of growth cause us to regress to that earlier stage. You might say that in this way globalization makes adolescents of us all.

Keeping Erikson's perspective in mind, I now want to spell out some of the ways in which globalization challenges us to rework our identity.

The first, and from my perspective as one who has lived and worked with essentially tribal societies, the most fateful of the changes globalization has wrought is the displacement of tradition from being simply "the way things are" to being but one choice among others. Anthony Giddens describes this as a consequence of modernity, but globalization will do as well, since the two are virtually coter- 
minous. ${ }^{5}$ As Giddens observes, prior to the concept of modernity, there was also no concept of tradition (and indeed most of the traditional societies I am familiar with have no indigenous term for tradition). What is, is simply what always was and always will be. Children could learn all they needed to know from their elders, because their elders had already experienced it. Modernity arrives offering a different perspective: today is not the same as yesterday, and tomorrow will bring something different yet. The expectation of change means that children can no longer count on learning what they need from their elders, because they will be confronted with things their elders never imagined.

What modernity does for time, globalization does for space. The awareness of different cultures, different loci of knowledge, different economic opportunities, makes remaining in one's home village no longer the obvious thing, but a fateful and often agonizing choice. Tradition emerges as a concept in the face of these twin challenges - no longer as a natural flow from generation to generation, but a field of contestation over what will be kept and what will be rejected, what will be passed on and what will be forgotten. To the degree that religious identity has been embedded in tradition (or rather in that nameless state of being that preceded it), it will also be up for renegotiation.

A second factor is the familiar bogey "secularization." Globalization dissolves the unity of sacred land/sacred history/sacred people to which communal religions aspire and opens up a value-neutral space in which by definition "nothing is sacred". ${ }^{6}$ Into this open playing field floods a river of global news and information, mutually indistinguishable smiling politicians, and shrieking advertisements and the bazaar of consumer goods they are designed to sell.

Religion itself enters this arena as a commodity. Muslim fashion is big business (Can clothing have a religion?), Christian evangelists package their tours like rock stars, books touting various theologies of success are best-sellers, and A.A. Gym made a fortune selling Muslim-tinged platitudes on TV spots and even by SMS.

A third factor pressing toward greater individuation comes from the development of a global hegemony of democracy and human rights as the frame-

\footnotetext{
5 Anthony Giddens, The Consequences... p. 37.

6 José Casanova, "Religion, the New Millenium, and Globalization." Sociology of Religion, (Vol. 62, No. 4, 2001), p. 425.
} 
work within which national politics and local policies are judged. Democracy has so dominated political discourse that it is now widely seen as the only legitimate form of governance. Even the most authoritarian political thugs feel compelled to dress themselves in the trappings of democracy. George Bush famously claimed, "I am the decider." What made his comment such a gaffe was not its quaint language so much as the fact that democracy assumes that all citizens, not just the President, are "deciders." The intensely individual aspect of being a democratic decider is aptly symbolized by the sacred privacy of the voting booth where one is alone with one's conscience. But outside the booth a battle over identity rages. The predominant politics of identity (more on that below) asks people to identify themselves by their votes: Muslim? Javanese? Working class? Nationalist? Sukarnoist? The political science term for this condition is appropriate to our topic: "voter confusion."

Finally, the discourse of human rights has also served to increase individuation within religious communities. While human rights is the closest thing we have to a global ethic, it has primarily framed that ethic in terms of the rights of individuals. Certain religiously-sanctioned practices have been challenged as violations of human rights, including child marriage, female circumcision, polygamy, the denial of education to women, and restrictions on the right to convert to another faith. The effect has been to reduce the authority of religious groups over their members and to strengthen the ability of the individual to choose his or her own path.

Such are the clichés of modernity. All I want to emphasize here is that their cumulative effect is increasingly to throw individuals back on their own resources, to create pressures toward ever greater individuation, to intensify the amount of psychic energy we exhaust in making choices, and to increase the possibility of identity confusion. At the same time, it offers new opportunities for growth and for finding a sense of responsibility/fidelity more adequate to the world we now live in rather than the world of our ancestors. This is the condition of the adolescent writ large, as Erikson describes it. It is in itself neither good nor bad. We just have to deal with it.

\section{E. Fragments of a Religious Sociology of Globalization}

Just as the various religions have different criteria for membership, so also they 
cultivate different forms of association among their followers. Muslims revere the ummah, the fellowship of all believers everywhere, even though they may feel only the loosest of bonds to any particular local community of faith. Christians tend toward the reverse, establishing relatively tightly-knit bonds to a local congregation with only a loose affiliation beyond their local community. The practice of Chinese traditional religion may center around an altar in the home. Some indigenous religions are so tied to place that they cease to function beyond the tribal territory. Ethnically based religious groups go where their people go, and stop where their people stop. Under these conditions, the social impact of globalization on religious groups will be highly variable. Since the religious group I know best is Protestant Christianity, allow me to speak of what I know and leave others to draw the implications by comparison.

\section{De-territorialization and Re-localization}

As we are entering the third millennium...we are witnessing the end of hegemonic European Christianity due to a dual process of advanced secularization in post-Christian Europe and of the increasing globalization of a de-territorialized and de-centered Christianity. Thus, the one thousand year old association between Christianity and Western European civilization is coming to an end. Western Europe is less and less the core of Christian civilization and Christianity in its most dynamic forms today is less and less European. ${ }^{7}$

The modern system of nation-states marked off the entire globe into bounded territories, each under the sovereignty of a state. The concept of citizenship likewise territorialized all people by marking them as belonging to one of these states. At the same time, the shadow of colonization left constellations of old and new states that shared a common if troubled history (e.g. the British Commonwealth, the French ties to North Africa, the relationship of Holland and Indonesia or the United States and the Philippines). Now, just as globalization has made these boundaries more porous (and some would say less significant) the boundaries of membership in religious communities are being both "compromised" and expanded.

To take the Protestant Church of Timor (the church I serve) as an example:

$7 \quad$ Ibid., p. 417. 
GMIT (its Indonesian acronym) is by its constitution a territorial church. It only establishes churches within the bounds of Nusatenggara Timur (minus Sumba, where it has a sister church, plus Sumbawa in NTB). A generation ago GMIT could have been called the folk church of Timor. Today, at least a dozen smaller denominations have grown up, following lines of institutional sponsorship that stretch back to Java and on to fundamentalist and Pentecostal groups in the United States. GMIT no longer has exclusive claim over the Protestants in its "own" territory. On the other hand, GMIT members have migrated to Sulawesi, Bali, Java, Batam, Malaysia, and Hong Kong, and there are increasing calls for GMIT to provide ministry to this diaspora. To further complicate things, GMIT's multilateral links include membership in the Indonesian Communion of Churches, the Protestant Church of Indonesia, the Christian Conference of Asia, the World Alliance of Reformed Churches, and the World Council of Churches; and its bilateral links include not only churches in Holland, but also in Australia, Ireland, Korea, and the United States.

A map of GMIT would thus include not only the islands of Nusatenggara Timur but also air and internet links to all of the above mentioned places and organizations, each of which is a point of encounter with "otherness" and a portal for influence on its own religious identity. For example, when the World Council of Churches proclaimed a decade of reflection on "the Community of Men and Women in the Church," GMIT dutifully mounted a series of bible studies and seminars, and the word "partnership" entered our vocabulary. Women were increasingly elected to church councils, and toward the end of that decade, the balance of men and women candidates for ministry shifted to a majority of women. Other social factors were at play to be sure, but the role of influence "from outside" is clear.

Paradoxically, this deterritorialization on a large scale has opened up a relocalization at the village level. The contextualization movement in postcolonial theology as it filtered down to local pastors served to "give permission" for the revival of local traditions and rituals, albeit with new Christian interpretations. Rituals of the agricultural cycle that played so important a role in indigenous religion were revived and reconfigured as Christian worship. Sacred spaces that were formerly anathema were reclaimed by local congregations, sometimes with their traditional functions intact as centers for agricultural prayers, and at other times with quite new associations. A traditionally sacred mountain of the 
people of Mollo stood alone for many years after it was identified as a place of idolatry by the church. But when it was targeted for marble mining, the people once again began worshipping there and used its renewed sacred status as a basis for their rejection of mining. They took as their text the opening words of Psalm 24: "The earth is the Lord's, and all that is in it."

Especially since the fall of Suharto, a kind of de-nationalization has also taken place. Where local congregations once hesitated to use indigenous languages in worship for fear that they would be considered unpatriotic, new liturgies and Bible translations in local languages are coming into use, along with the use of traditional music and art. Where GMIT once took its cues on national issues from the Indonesian Communion of Churches in Jakarta, it is increasingly going its own way - most notably in its public support for the 1999 referendum on independence for East Timor.

\section{The Spectre of Comparisons}

Along with deterritorialization comes a realignment due to the expanding number of bilateral and multilateral contacts that local religious communities develop with co-religionists beyond their borders. As a result, the religious communities cannot avoid comparing themselves with one another. Post-colonial religious communities now have more models, more mirrors in which to see their reflection than that offered by the colonial "parent." For Christians this is part of the de-centering of Euro-American Christianity that Casanova notes above.

But as Ben Anderson captures in a phrase from the Filipino novelist Jose Rizal, this does not mean a declaration of independence. It means the religious communities are haunted (or inspired) by the "spectre of comparison" with other expressions of the same faith. ${ }^{8}$ Matters such as the ordination of women, treatment of homosexuals, open communion, the role of the laity, clergy compensation, educational requirements for ministry, political engagement, concern for the environment, and many more, are thrust before the religious community whether they are ready to deal with them or not. Of course they may shut their eyes and ears, and they often do, but the spectre of comparison haunts them still.

\footnotetext{
8 Benedict Anderson, The Spectre of Comparisons, (London: Verso, 1998), p. 2.
} 
To some degree, the same kind of comparison takes place in interfaith dialogue, but in that case we expectthere to be differences, and are delighted whenever we find that they aren't as great as we had imagined. But in the interplay of communities within the same religion we expect things to be the same, and are alarmed when they are not. In my observation intra-faith dialogue is by far the greater challenge to religious identity than interfaith dialogue.

\section{The Politics of Religious Identity}

To speak of religious identity almost seems redundant. Religion is all about identity, from the rites of initiation found in most tribal religions to the pesantren and the Sunday school. Even our very names are often drawn from a pool of approved "Christian" or "Islamic" names. But as Amartya Sen has argued (against Samuel Huntington's "clash of civilizations" thesis), most of us form significant social bonds along quite different lines as well. Not only the waning power of nationalism binds us together, but smaller associations such as neighborhoods, extended families (which are increasingly multi-religious), trade unions, educational institutions - even the Global Fellowship of Manchester United Fans. ${ }^{9}$

Sen's wisdom notwithstanding, perhaps because religious identity embodies our relationship to God, not just to our neighbors; it is an exceptionally easy target for those who would manipulate it with a politics of identity. Defense of religion is certain to draw many brave volunteers, even from those who don't normally darken the door of their local place of worship. Of course the idea that the Creator of heaven and earth would need our feeble arms to be raised in God's defense is theologically puzzling. But to the degree that Durkheim was right, and religion becomes the divinization of our group identity, it provides a marvelous flag under which to rally the troops. Perhaps that is why when I add the words "globalization" and "religious identity," the next word that comes to mind is "conflict." Let me provide the closest thing I have to a first-hand example.

In 1998 there were riots in Kupang. The spark was a rumor that Muslims had burned the cathedral in the center of town. Although false, the rumor

9 Amartya Sen, Identity and Violence, (New York: Norton, 2006). 
seemed plausible in view of the church burnings that had been taking place in Java during the previous few years. Roads were closed and phone lines shut down (we still don't know by whom) so that it was difficult to verify and counter the rumor. In a matter of hours "Christians" had looted and burned the homes and businesses of "Muslims."

Why put the names of the two groups in quotation marks? Because we could just as easily describe the rioting in a different way: day laborers raided shop owners, or local fishermen drove off migrant fishermen, or Rotenese attacked Bugis. We could also say "National minority/local majority" attacked "National majority/local minority." Or we could say it was all someone's idea of a practice exercise for East Timor, Maluku, and Poso. True, there was a religious face to the conflict, but its hands and feet may have been something quite different: class conflict, conflict among economic competitors, ethnic conflict, regionalism, or an experiment in crowd manipulation.

My point is that we would miss the truth about what happened if we focused only on religious identity. Speaking of the effect of globalization on religious identity is endlessly complicated because globalization impacts all other aspects of our identity at the same time.

Yet another problem lurks beneath the surface. The looters and rioters were mostly young men, a great many of whom were only marginally involved in the religious life of their churches. They weren't church youth groups taking torch in hand. There were also many Christians who tried to stop the rioting or who gave shelter to their Muslim neighbors. The dormitories of the Protestant theological school were filled with Muslims fleeing the violence. A church youth group evacuated a fleet of buses belonging to a Haji in their neighborhood so they wouldn't be destroyed, and pastors went onto the streets to plead with the crowds to stop. When we speak of "religious identity" in this situation, whose identity do we speak of? The Christian rioters or the Christian neighbors? Of course we need to speak of both, but we must beware of making generalizations that hide more than they reveal.

Having said this, I want to proceed to make three generalizations.

First, a politics of religious identity almost always has at its core a perceived threat to the community; whether the threat is realistic or symbolic seems to 
make little difference. Church burnings in Java had left Christians in Timor fearful of what may lie ahead, despite their status as a local majority. Identity politics is by no means limited to minorities. The pluralism and deterritorialization brought by globalization may give rise to a "fortress mentality" even among majority groups. Muslim political activism in Indonesia and many other countries with Muslim majorities has been matched in the United States by the entry of Christian Evangelicals into a kind of political activism that has not previously characterized their faith. $70 \%$ of them voted for George Bush in 2004. (Although Protestants who identify themselves as Evangelicals are far from a majority, making up just $26.3 \%$ of the U.S. adult population [according to a 2008 Pew Foundation survey], they do comprise the largest single Protestant group.) A variety of issues motivated this newfound activism, but perhaps the phrase most often heard was "defense of the American way of life." Whatever that is. This group was also most likely to cite "terrorism" as the greatest threat to the country.

The likelihood that a perceived threat will draw a religious community into identity politics seems greatly increased in contexts such as Indonesia where there is state sponsorship and regulation of religion. In a pattern that often resembles patron-client relationships, religious groups cultivate favored status with local authorities, compete for funding against one another and quickly appeal to civil authorities to resolve their differences rather than talking directly to one another, as they would do if the state were not involved. It seems inherent in state sponsorship of religion that religion will in turn be politicized.

Second, the fact that so much of religious identity is expressed symbolically also renders it open to identity politics. If you want to start a riot in Flores, smash a communion wafer; if you want to rile up the local Muslims, spread a rumor that someone stepped on the Al-Quran (both of which have happened in NTT). Conversely, some Christian women wear the jilbab in certain areas in order not to be harassed, and during the 1998 rioting Muslim shopkeepers in Kupang painted crosses on their doors in hopes of escaping the looters. Religious symbols offer a convenient "handle" by which political actors can grasp the community's allegiance. Since so much of electoral politics involves the manipulation of symbols, we should not be surprised if politicians have developed more expertise in this area than many religious leaders. 
Third, a politics of identity by its nature falls short of the basic function of politics itself. I understand politics as a collective answer to the question, "How shall we live together?" The "we" in question must include all the people who live within the territory governed by the political process. When groups, whether majorities or minorities, engage in a politics of identity, they are making claims that apply only to the members of their group: "This is how we want to live together within our group." Such an approach is inherently divisive and incapable by itself of answering the fundamental political question: how are we to live together with people who are not part of our group (whether we define it religiously, ethnically, or racially), but who are nonetheless fellow citizens?

Identity politics can, however, serve to crystallize group identity and claim a stake in a larger political process. A prayer rally held by the Serbian Orthodox Church in newly independent Kosovo (where Serbs are a 10\% minority) clearly had that function. "We want to prove we exist," their patriarch said. In France, Muslim groups are struggling for the right of women to wear an Islamic head covering in public; in Egypt, Iran, and a number of other predominantly Muslim countries, there is a struggle over the right not to wear it. In both cases, those who are socially positioned as minorities are struggling for recognition of their right to be who they are.

This analysis gives us one way of looking at the difference between the "Christian rioters" and the "Christian neighbors" in the example from Kupang above. The rioters opted for a politics of identity (not that they could have explained it to you), while the "neighbors" opted for a politics of inclusion (which they may well have been able to explain quite clearly). As religious groups in Indonesia consider how to position themselves in the emerging Indonesian democracy, these issues will be of increasing importance.

\section{Hybridity and Heresy}

The capacity of global commerce and communications technology to "bring the world to our doorstep," as well as a vast increase in the level of mobility and migration among peoples has produced a historically unprecedented mixture of cultures, products, and ideas in even the most remote areas of the globe. The condition of being confronted with so many choices from so many directions on a daily basis has been aptly termed hybridity. There has been a fairly consistent 
tension between those who accept hybridity as an inevitable part of the modern condition and those who see it as a threat to religious identity. I think both points of view are true. In fact they form a syllogism, the conclusion of which is that the modern condition of hybridity is a threat to religious identity from which we cannot escape. As I said above, we just have to deal with it. There is a rather nasty theological category for dealing with threats to religious identity, and I think it needs to be inserted into the discussion: heresy. I don't know what the Arabic term for it is, but I'm sure there is one.

As long as the religious other is simply other, outside the sphere of our religious community, there is no question of heresy but only of difference. It's okay for Christians to eat pork, but not for Muslims or Jews. It's okay for women to be ordained to the priesthood in most Protestant Churches, but not in the Roman Catholic Church. We're just different that way.

Heresy becomes a possibility if a belief from "outside" begins to make its way "inside" and to lure the interest of our own religious community. If the attraction is strong enough to lure someone out of their previous religious affiliation and into a new one, it is called "conversion"; if the lure is definitively rejected by the religious community (or its duly appointed authorities) it is labeled heresy. Between the two poles of decisive acceptance and decisive rejection lies the rich and complex territory of hybridity.

The original Greek root of the word "heresy" means "choice." By implication, those who commit heresy have made a choice which places them at odds with the commonly held values and beliefs of their community, and which may lead either to their remaining within the community even while they feel a sense of alienation, leaving the community voluntarily, or being expelled from the community. In light of the increased pressure toward individuation and the multiplication of choice we noted earlier, we should expect that one effect of globalization on religious identity is a marked increase in the number of "heretics" lurking among us.

Border situations in which identity is contested, bargained or negotiated thus raise the possibility of conversion, heresy, or hybridity. (Here we should note that far from producing a borderless world, globalization has greatly intensified our experience of border situations in daily life, making liminality almost the norm.) The choices are basically to synthesize the other, to adopt it and leave something of our old self behind, or to reject the other. 
Of course one person's hybridity is another person's heresy - but in either case there is an act that clarifies one's religious identity. In the plural environments of globalization these acts of identification are taking place at a rapid rate among millions of individuals. When enough individuals in the same environment make similar choices, a social trend begins to emerge, which may eventually come to the attention of the border guards of faith communities affected by them. Meetings are called, committees are formed, positions are taken, and eventually a formal pronouncement is issued. This is the peculiar branch of theology that Daniel Boyarin has called "heresiology". ${ }^{10}$ A border line is drawn marking the outer boundaries of the faith: inside the line is "Okay" and outside the line is "Not Okay."

The reflexive movement from personal choice to social trend to public issue has always been with us; the engines of globalization merely accelerate and publicize it. This process is aptly illustrated in the issue of the role of gays and lesbians in Christian churches. There have always been gay people in church, including gay pastors and gay couples. But there was an unspoken agreement for gays to remain in the closet and for heterosexuals not to notice. Beginning in the 1960s in concert with women's, racial, and ethnic liberation struggles, a social movement grew in the United States and Europe to win acknowledgement of the full humanity of gay people. More and more gays refused to hide their identity any longer, and made the difficult decision to "come out" into the public space. Albeit a bit behind the curve, this started happening in the churches: gay pastors "came out" to their congregations, gay believers began presenting themselves for ordination, and gay couples asked the churches to bless their union. This called out the religious border guards, and the battle was joined.

Many Protestant denominations settled the matter very quickly: homosexuality is a sin from which Christians are called to repent, gay couples are doubly living in sin (because they are both gay and having sex outside the bonds of marriage), and gays are barred from ordained ministry. My own denomination took the opposite course: we affirmed the full humanity of gays and lesbians, agreed to consecrate their marriages, and to ordain openly gay persons - while

10 Daniel Boyarin, in Loomba, ed 2005: 339-358, cited in Susan Abraham, "What does Mumbai have to do with Rome? Postcolonial Perspectives on Globalization and Theology," (Theological Studies, Vol. 69, 2008), p. 382. 
at the same time stressing that gays have the same calling to responsible and faithful sexual relations as heterosexuals. We immediately lost about 100 congregations and thousands of members. But we also gained new members, who were attracted to a religious community that was "open and affirming" (as the denominational jargon put it).

The resulting shift in religious identity is obvious: a clarification of values on both sides of the issue, a fragmentation of existing alliances, and the formation of new ones. For the churches that opened their doors to gays and lesbians there has been a remarkable process of discovery and education about the varieties of being human. For those who closed their doors, we should note that rejecting heresy is just as much a shift in religious identity as hybridity. The refusal to accept change itself marks a change from a formerly more flexible position to a more rigid one. Over time, the religious community shaped by the rejection of heresies comes to be defined by the enemies it has fought. As a result, it is much clearer about what it is against than what it is for.

But how does this apparently Euro-American phenomenon relate to globalization? In at least two ways. First, the liberation movements of which gay liberation was a part were inspired by postcolonial struggles and theories of resistance, from Mahatma Gandhi to Franz Fanon to the liberation theologies of Latin America. Activists in North American liberation movements were much quicker than mainstream intellectuals to recognize that postcolonial theory applied just as much to the United States as to Africa, Latin America, and Asia. Unfortunately, when the same arguments about liberation from oppression shifted from race to sexual orientation, many "liberationists" choked.

Second, the struggle for gay rights in the churches of the United States has not occurred in secret. Aside from global media coverage, most of the major denominations have both historic and affiliation ties with churches around the globe. For example, this global connection has led the Anglican Church to the verge of schism. The ordination of an openly gay priest as Bishop in the United States was met with cries of heresy, principally under the leadership of the Anglican communions of Britain's former African colonies. Meeting in Jerusalem, they issued a statement on the "Global Anglican Future" in which they outlined a virtual church within the church, in which homosexuals are only welcome if they are celibate, and are unacceptable as priests. Thus by crying heresy the 
African Anglicans have repositioned themselves as guardians of the authentic tradition, while North American and English Anglicans are apostate.

This kind of challenge to religious identity cuts deeply. For the African Anglicans to engage in dialogue with the "hybridizing" North Americans, they would be forced to reconsider their understanding of biblical authority. To be sure, the Bible condemns homosexuality. It is seen as a perverse rebellion against our divinely created nature. But many in the U.S. are convinced by scientific evidence and daily experience that homosexuality is genetically influenced, and therefore in some sense natural. If so, the Bible may be mistaken about homosexuality just as it was mistaken about the shape of the earth and the position of the sun. Are African Anglicans prepared to reexamine their assumptions about the authority of the Bible for the sake of a few gays? More to the point, are they ready to reconsider their own cultures' concepts of human sexuality? It is much easier to cry heresy.

\section{Theology and Globalization}

When we speak of religious identity often the focus is on scriptures, official teachings, rituals, and polity. While these things are important, they are only a part of what gives a religious community and its members their sense of self, their sense of belonging, their sources of meaning and purpose. Common history, personal experiences, family connections and friendships, culturally-inspired traditions that may be on the margins of orthodoxy - all have as much to say about who we are as people of faith as the formal aspects of our religion. Very often people of faith are far more humane than their dogmas.

That said, we can hardly deal with globalization and religious identity without touching on the aspect of ideational formation within the community of faith. Christians call it theology. Unfortunately this topic is so broad as to cover almost the entirety of significant Christian theological development in the last twenty years. I mark that date from the early 1990s, when the American Association of Theological Schools began its "Globalization of Theological Education" initiative, ${ }^{11}$ in which all member schools were required to introduce the

11 Evans, Alice, \& David A. Roozen, eds, The Globalization of Theological Education, (Maryknoll: Orbis, 1993). 
perspective of globalization into their curricula for accreditation purposes. This well-intentioned plan threatened to set off a major brain drain as North American seminaries rushed to hire the cream of third world theologians. The date could as easily go back forty years, to the founding of the Ecumenical Association of Third World Theologians in Dar es Salaam, Tanzania in 1976. Or we could go back further to the decades-long global dialogues that eventually led to the formation of the World Council of Churches in 1948. And this only takes into account theological reflection in which there is significant multi-national participation. If we were to consider theologies of globalization, the date would have to go back to the founding of Christianity itself. I have no idea what the Muslim history has been, but I suspect it has been equally intense.

This being the case, I can only manage a few very general observations.

First, and in some ways most interestingly, theology has become a more generative discipline. By that I mean that it has been largely freed from the burden of buttressing the historic teachings of the church with ever more elaborate articulations. Theology in the style of Karl Barth, which seems to be delivered like the Ten Commandments from the top of Mt. Sinai, has stagnated, while the more confessional and socially-located theologies of gender, class, and ethnicity have shown the greatest vitality. This is not an abandonment of tradition so much as an ongoing creative response to new realities not foreseen in the tradition.

Second, theology has become a more public discipline. The opening of global media combined with global linkages among faith communities means not only that religious discourse reaches a wider audience, but that what theologians say has to take account of who will hear it. It is increasingly difficult to say one thing in private and another in public. Moreover, theologians can no longer assert "We're special" and turn their backs on other disciplines. As Susan Abraham puts it:

The claim of religion and theology to be sui generis fields requiring protective strategies such as excluding social, cultural, ethical, theoretical, or political methods to verify the intelligibility of its assertions is being steadily assailed by globalization and postcolonial theories. ${ }^{12}$

12 Susan Abraham, "What does..., p. 377. 
Third, theologies of mission, which are charged with articulating what a religious body is called to do in the world, have had to be thoroughly rethought. Among Christians, the idea of "bringing the world to Christ in our generation" that inspired a generation of young missionaries a century ago seems as quaint as a $19^{\text {th }}$ Century science fiction novel. Both Christians and Muslims indeed have a globalization of faith as part of their belief system. This seems to be inherent in monotheism: monotheism implies a world, a universe: creation is one because there is but one Creator. But monotheism does not necessarily imply monoreligion. Just as there is a great diversity in God's creation, there is a great diversity of ways to worship God.

\section{F. Concluding Remarks}

Here lies the great divide for monotheistic faith: do we see our conviction of One God, One World, as a mandate for world conversion to our religion or as a mandate to care for the earth and to embrace our common humanity? Those who aim for a universal conversion to their faith will be frustrated by globalization because it constantly brings them face to face with the reality (and vitality) of other religions. Those who see in their faith a mandate to care for others and for the earth we all share as part of God's creation will not be threatened by globalization, although they will be challenged to articulate and enact their universal faith.

The U.S. denomination of which I am a part (The United Church of Christ) has clearly and repeatedly chosen the latter course. A sample of the dozens of declarations that come out annually from our denominational offices includes condemnation of the invasion of Iraq, condemnation of the use of torture by agents of the United States Government, a call for more just international trade agreements, and countless resolutions calling on Israel to behave in a less beastly manner toward the Palestinians. This provides a fair picture of the theology of global missions currently operative in many liberal Protestant denominations.

Admittedly, many Christians would not be satisfied with such an articulation of the mission of the church. "Where is Jesus Christ in this?" they might ask. To which I would reply, "Probably with the Palestinians, the Iraqis, and the prisoners in Guantanamo." 
However the question of global mission is answered by our religious communities, I want to conclude with a plea to both Christians and Muslims that we take our monotheism more seriously. We should perhaps be less concerned with the names by which people call the one God, or whether they have a name at all; if there is indeed but one God, then there is no possibility of worshipping another, and every prayer arrives at the same destination. We should be more concerned about reasserting our common humanity, for this is perhaps the most convincing way we have now of proclaiming that we come from one divine source. We can embrace globalization as our ancient heritage and take responsibility for wresting it from the hands of global greed. Surely that is better and more faithful than fleeing from it as if we were refugees from the realm of Satan.

\section{BIBLIOGRAPHY}

1963. The Responsible Self. New York: Harper.

2003. Runaway World: How Globalization is Reshaping Our Lives. New York: Routledge.

Abraham, Susan. 2008. "What does Mumbai have to do with Rome? Postcolonial Perspectives on Globalization and Theology," Theological Studies, Vol. 69, hal. 376-393

Anderson, Benedict 1998. The Spectre of Comparisons. London: Verso.

Augsburger, David W. 1986. Pastoral Counseling Across Cultures. Philadelphia: Westminster Press.

Balasuriya, Tissa. 1994. Teologi Siarah. Jakarta: BPK.

Borrong, Robert P. 1999. Etika Bumi Baru. Jakarta: BPK.

Bourdieu, Pierre et al 1993. The Weight of the World: Social Suffering in Contemporary Society. Stanford: Stanford University Press.

Brecher, Jeremy; Tim Costello dan Brendan Smith 2000. Globalization from Below: The Power of Solidarity. Cambridge, MA: South End Press.

Brubaker, Pamela K. 2001. Globalization at What Price? Economic Change and Daily Life. Cleveland: Pilgrim Press.

Buell, Frederick 1994. National Culture and the New Global System. Baltimore: Johns Hopkins University Press.

Burawoy, Michael et al 2000. Global Ethnography. Berkeley: University of California Press. 
Casanova, José 2001. "Religion, the New Millenium, and Globalization." Sociology of Religion, Vol. 62, No. 4, hal. 415-441.

Chossudovsky, Michel 1997. The Globalisation of Poverty: Impacts of IMF and World Bank Reforms. Penang: Third World Network.

Cobb, John B. 1992. Sustainability. Maryknoll: Orbis.

Dante 1949. The Divine Comedy. Trans. Dorothy Sayers. Baltimore: Penguin.

Duchrow, Ulrich. 1999. Mengubah Kapitalisme Dunia: Tinjauan Sejarah-Alkitabiah bagi Aksi Politis. Jakarta: BPK.

Ellison, Marvin Mahan. 1983. The Center Cannot Hold: The Search for a Global Economy of Justice. Washington: University Press of America.

Ellwood, Wayne 2001. The No-Nonsense Guide to Globalization. Oxford: New Internationalist.

Erikson, Erik 1985. The Life Cycle Completed. New York: Norton.

Evans, Alice dan Robert, David Roozen, eds. 1993. The Globalization of Theological Education. Maryknoll: Orbis.

Fakih, Mansour 2002. Runtuhnya Teori Pembangunan dan Globalisasi. Yogyakarta: Insist Press.

Friedman, Thomas L. 2005. The World is Flat. New York: Farrar, Strauss, Giroux.

Giddens, Anthony. 1990. The Consequences of Modernity. Stanford: Stanford University Press.

Gills, Barry K., ed. 2000. Globalization and the Politics of Resistance. New York: Palgrave.

Hertz, Noreena 2001. The Silent Takeover: Global Capitalism and the Death of Democracy. New York: Free Press.

Heslam, Peter 2004. Globalization and the Good. Grand Rapids: Eerdmans.

Hoogvelt, Ankie 2001. Globalization and the Postcolonial World: The New Political Economy of Development. Baltimore: Johns Hopkins University Press.

International Forum on Globalization 2002. Alternatives to Economic Globalization: A Better World is Possible. San Fransisco: Berrett-Koehler.

Knitter, Paul F. 1996. Jesus and the Other Names: Christian Mission and Global Responsibility. Maryknoll: Orbis.

Kung, Hans, dan Karl-Josef Kuschel. 1999. Etik Global. Yogyakarta: Pustaka Pelajar. 
Loomba, Ania et al, eds. 2005. Postcolonial Studies and Beyond. Durham, N.C.: Duke University.

Mittelman, James H. 2000. The Globalization Syndrome: Transformation and Resistance. Princeton: Princeton University Press.

Morley, David, dan Kevin Robins 1995. Spaces of Identity: Global Media, Electronic Landscapes and Cultural Boundaries. New York: Routledge.

Niebuhr, H. Richard. 1962. Radical Monotheism and Western Culture. New York: Harper.

Ritzer, George 2006. The Globalization of Nothing: Mengkonsumsi Kehampaan di Era Globalisasi. Yogyakarta: Universitas Atma Jaya.

Robertson, Roland 1992. Globalization: Social Theory and Global Culture. London: Sage.

Ruether, Rosemary Radford. 1992. Gaia and God: An Ecofeminist Theology of Earth Healing. San Fransisco: Harper Collins.

Sen, Amartya 2006. Identity and Violence. New York: Norton.

Setiawan, Bonnie 2001. Menggugat Globalisasi. Jakarta: INFID.

Van Drimmelen, Rob. 1998. Faith in a Global Economy: A Primer for Christians. Geneva: WCC Publications.

Wicks, Robert J. dan Barry K. Estadt, eds. 1993. Pastoral Counseling in a Global Church. Maryknoll: Orbis.

Wilson, H.S. et al. 1997. Pastoral Theology from a Global Perspective. Maryknoll: Orbis.

Wilson, Rob, dan Wimal Dissanayake, eds. 1996. Global/Local: Cultural Production and the Transnational Imaginary. Durham: Duke University Press. 